DOI: $10.5965 / 25946412222018127$

\title{
A EXTENSÃO COMO ESPAÇO PARA APLICAÇÃO DE METODOLOGIAS ATIVAS DE ENSINO-APRENDIZAGEM NA FORMAÇÃO DO ESTUDANTE DE MEDICINA
}

\author{
Jéssica Silva Lannes \\ Universidade Estadual do Ceará \\ iessica.lannes@aluno.uece.br \\ Allyson Wosley De Sousa Lima \\ Universidade Estadual do Ceará \\ allvsson.woslev@aluno.uece.br \\ Alanna dos Santos Delfino \\ Universidade Estadual do Ceará \\ alanna.delfino@vahoo.com.br \\ Thais Campelo Bedê Vale \\ Universidade Estadual do Ceará \\ thaisbede1@gmail.com \\ Edite Carvalho Machado \\ Universidade Estadual do Ceará \\ edite.machado@aluno.uece.br \\ Letícia Ramos Vieira \\ Universidade Estadual do Ceará \\ leticiavieira@hotmail.com \\ Gisele Nogueira Bezerra \\ Universidade Estadual do Ceará \\ gnogbez@gmail.com \\ Tatiana Paschoalette Rodrigues Bachur \\ Universidade Estadual do Ceará \\ tatiana.bachur@uece.br
}

\section{Resumo}

Esse estudo é um relato de experiência de acadêmicos do curso de graduação em Medicina da Universidade Estadual do Ceará (UECE) acerca da vivência do projeto de extensão universitária Reanimação Cardiopulmonar ( $\mathrm{RCP}$ ) para Todos, um projeto educativo teórico-prático que promove conhecimento para comunidade e para os acadêmicos da Liga Acadêmica de Cardiologia (LICARDIO) do curso de Medicina da UECE. Esse projeto tem como objetivo capacitar a comunidade para socorrer adequadamente as vítimas de Parada Cardiorrespiratória (PCR), com o intuito de aumentar a sobrevida

Cidadania em Ação: Revista de Extensão e Cultura, Florianópolis (SC), v. 2, n.2, jul./dez. 2018. 
desses indivíduos e consta com duas etapas de aprendizado. Inicialmente são realizadas capacitações internas com os membros da LICARDIO por meio de seminários teóricos ministrados pelos próprios acadêmicos. A partir disso, são realizadas as intervenções do projeto de extensão com a comunidade. Nessas intervenções, são iniciadas as capacitações com o público por meio de exposição oral sobre a PCR, após a teoria é iniciado o treinamento prático de simulação da PCR com manequins próprios para a atividade de RCP. As atividades de educação em saúde que compõem o projeto impactam diretamente na sobrevida de pacientes vítimas de PCR se mostrou também um rico campo de práticas nos moldes das metodologias ativas em que o discente assume a posição principal na busca e formação do conhecimento. Conhecimento esse não alheio à realidade que o cerca, mas que dialoga e troca com a mesma no sentido de formar profissionais que saibam responder às demandas da sociedade e que compreendem o processo saúde-doença como um complexo sistema de variáveis sociais, ambientais e biológicas.

Palavras-chave: Metodologias Ativas. Reanimação Cardiopulmonar. Parada Cardiorrespiratória

\title{
EXTENSION AS A SPACE FOR THE APPLICATION OF ACTIVE METHODOLOGIES OF TEACHING-LEARNING IN TRAINING OF THE STUDENT OF MEDICINE
}

\begin{abstract}
This study is an experience report of undergraduate medical students from the State University of Ceará (UECE) about the experience of the university extension project Cardiopulmonary Resuscitation (CPR) for All, a theoretical-practical educational project that promotes knowledge for the community and for the academics of the Academic League of Cardiology (LICARDIO) of the UECE Medicine course. This project aims to enable the community to adequately assist the victims of Cardiopulmonary Arrest (CRP), in order to increase the survival of these individuals and consists of two stages of learning. Initially, internal trainings with the members of LICARDIO are carried out through theoretical seminars given by the academics themselves. From this, the extension project interventions with the community are carried out. In these interventions, the training with the public is initiated through oral exposure on PCR, after the theory is started the practical training of simulation of the PCR with mannequins fit for the activity of CPR. The health education activities that make up the project have a direct impact on the survival of patients who are victims of CRP. It has also shown a rich field of practice in the form of active methodologies in which the student assumes the main position in the search and formation of knowledge. This knowledge is not alien to the reality that surrounds it, but dialogues and exchanges with it to create This knowledge is not alien to the reality that surrounds it, but dialogues and exchanges with it to create professionals who know how to respond to the demands of society and who understand the health-disease process as a complex system of social, environmental and biological variables.
\end{abstract}

Key words: Active Methodologies. Cardiopulmonary resuscitation. Cardiopulmonary arrest

\section{LA EXTENSIÓN COMO ESPACIO PARA APLICACIÓN DE METODOLOGÍAS ACTIVAS DE ENSEÑANZA-APRENDIZAJE EN LA FORMACIÓN DEL ESTUDIANTE DE MEDICINA}

\begin{abstract}
Resumen
Este estudio es un relato de experiencia de académicos del curso de graduación en Medicina de la Universidad Estatal de Ceará (UECE) acerca de la vivencia del proyecto de extensión universitaria Reanimación Cardiopulmonar ( $\mathrm{RCP}$ ) para Todos, un proyecto educativo teórico-práctico que promueve conocimiento para la comunidad y para los académicos de la Liga Académica de Cardiología (LICARDIO) del curso de Medicina de la UECE. Este proyecto tiene como objetivo capacitar a la comunidad para socorrer adecuadamente a las víctimas de Parada Cardiorrespiratoria (PCR), con el objetivo de aumentar la sobrevida de esos individuos y consta con dos etapas de aprendizaje. Inicialmente se realizaron capacitaciones internas con los miembros de LICARDIO por medio de seminarios teóricos impartidos por los propios académicos. A partir de eso, se realizan las intervenciones del proyecto de extensión con la comunidad. En estas intervenciones,
\end{abstract}

Cidadania em Ação: Revista de Extensão e Cultura, Florianópolis (SC), v. 2, n.2, jul./dez. 2018. 
se inician las capacidades con el público a través de la exposición oral sobre la PCR, después de la teoría se inicia el entrenamiento práctico de simulación de la PCR con maniquíes propios para la actividad de RCP. Las actividades de educación en salud que componen el proyecto impactan directamente en la supervivencia de pacientes víctimas de PCR se mostró también un rico campo de prácticas en los moldes de las metodologías activas en que el alumnado asume la posición principal en la búsqueda y formación del conocimiento. Este conocimiento no es ajeno a la realidad que lo rodea, pero dialoga y cambia con la misma para crear profesionales que sepan responder a las demandas de la sociedad y que comprenden el proceso salud- enfermedad como un complejo sistema de variables sociales, ambientales y biológicas.

Palabras clave: Metodologías Activas. Reanimación Cardiopulmonar. Parada Cardiorrespiratoria. 


\section{INTRODUÇÃO}

A parada cardiorrespiratória (PCR) é um evento dramático, de morbimortalidade elevada, definido como a interrupção das atividades respiratória e circulatória efetivas (LUCIANO et al., 2010). Estima-se que a cada minuto de permanência em PCR há uma diminuição de $10 \%$ na probabilidade de sobrevida do indivíduo, portanto o tempo é um fator importante durante uma PCR (PAZIN-FILHO et al., 2003).

No Brasil, as doenças do aparelho cardiovascular foram responsáveis por $28 \%$ das mortes no ano de 2016, sendo assim a principal causa de morte em nosso país nesse ano (BRASIL, 2017). Esses dados revelam que a PCR, independente da sua etiologia, é a principal causa de morte imediata em nosso país, o que revela a importância da reanimação cardiopulmonar (RCP) no âmbito da Saúde Pública.

A RCP é um conjunto de procedimentos de emergência que visa a restabelecer a oxigenação e a circulação prejudicadas durante uma PCR. Em nosso país estima-se que ocorram 200.000 PCR's por ano, sendo metade dos casos ocorrendo em ambiente extrahospitalar como residências, shopping centers, aeroportos, estádios, entre outros (GONZALEZ, 2013). Como na PCR o tempo é essencial, é importante que pessoas leigas que presenciam uma situação de PCR ajam de imediato (PAZIN-FILHO et al., 2003). Porém, as principais justificativas dos leigos para não realizarem a massagem cardíaca são o desconhecimento do que fazer ou o medo de prejudicar ainda mais a vítima (PERGOLA; ARAUJO, 2009). Aqui reside a importância do treinamento de leigos que frequentam esses espaços e que possam maximizar a sobrevida do paciente até que chegue o serviço móvel de emergência (MORAIS, 2014).

Nesse contexto, foi criado, por iniciativa dos alunos do curso de medicina da Universidade Estadual do Ceará (UECE) então membros da Liga Acadêmica de Cardiologia (LICARDIO), em 2016 o projeto de extensão Reanimação Cardiopulmonar para Todos (RCP Para Todos), vinculado ao Centro de Ciências da Saúde, ao Curso de Medicina e à PróReitoria de Extensão (PROEX) UECE. O projeto está agora em sua $3^{\text {a }}$ edição e tem como objetivo capacitar o público-alvo para agir em socorro às vítimas de PCR, ensinando a população atendida, segundo as recomendações das diretrizes internacionais de reanimação da American Heart Association (AHA), a realizar as manobras de RCP e as ações que compõem o Suporte Básico de Vida (SBV).

Cidadania em Ação: Revista de Extensão e Cultura, Florianópolis (SC), v. 2, n.2, jul./dez. 2018. 


\section{METODOLOGIA}

Antes de iniciar-se o ciclo de intervenções junto ao público-alvo, há primeiramente uma capacitação interna dos alunos através de seminários sobre temas relacionados à PCR e à RCP. Quem ministra os seminários são os próprios acadêmicos. É realizado um sorteio prévio que determina quem irá expor um tema específico para os demais extensionistas. A partir disso, são realizadas as intervenções com duração de aproximadamente cinco horas, período em que ocorre a capacitação que se dá por meio de exposição oral sobre o tema mesclado com simulação de PCR nos manequins, permitindo que os participantes possam colocar em prática o que foi ensinado, corrigindo ativamente os erros, tornando o ensino mais efetivo. Essas ações são de participação livre e são realizadas uma vez ao mês, tanto na UECE, campus Itaperi, quanto em uma instituição religiosa que se localiza nos arredores da universidade. Para que tudo seja possível, o RCP Para Todos dispõe de recursos audiovisuais para as exposições teóricas e materiais para as aulas práticas, que inclui manequim para treino da RCP. Em cada exposição teórica, através de diálogo e usando os recursos audiovisuais, são apresentados a importância da RCP; as técnicas de compressão torácica e ventilação e o uso do desfibrilador externo automático (DEA).

Na parte prática, é exposta uma situação de PCR, tentando introduzir o participante em um contexto próximo do real, permitindo que os participantes têm a oportunidade de treinar não só as técnicas no manequim, bem como exercitar o raciocínio e a tomada de decisão num momento tão delicado.

A importância dessas ações, que impactam diretamente na sobrevida de pacientes vítimas de PCR, não reside apenas nisso, mas também na criação de um rico campo de práticas nos moldes das metodologias ativas que a experiência em extensão pode se tornar (DEUFEL et al., 2014). A metodologia ativa é uma concepção educativa que estimula processos de ensino-aprendizagem crítico-reflexivos, no qual o educando participa e se compromete com seu aprendizado. O método propõe a elaboração de situações de ensino que promovam uma aproximação crítica do aluno com a realidade; a reflexão sobre problemas que geram curiosidade e desafio; a disponibilização de recursos para pesquisar problemas e soluções; a identificação e organização das soluções hipotéticas mais adequadas à situação e a aplicação dessas soluções (BERBEL, 1998; BORDENAVE et al., 1982).

\section{A extensão e a aplicação de metodologias ativas}

As metodologias ativas se baseiam na reflexão crítica da realidade, desenvolvimento da autonomia e respeito aos saberes do educando, humildade e curiosidade (FREIRE, 1992).

Cidadania em Ação: Revista de Extensão e Cultura, Florianópolis (SC), v. 2, n.2, jul./dez. 2018. 
O estudante pode, através da pesquisa e busca por conhecimento para a produção de cada seminário e nas reuniões de equipe, em que ocorre embate de visões de mundo e construção coletiva por meio do trabalho em equipe, exercer esses princípios e aplicá-los também durante as atividades junto à comunidade. As ações do RCP Para Todos se afastam da educação bancária descrita por Freire, 1992, que apenas leva o conhecimento da universidade para fora de forma unilateral e não estimula adequadamente o desenvolvimento de autonomia, capacidade de análise, julgamento e avaliação, bem como raciocínio crítico, investigativo e criativo; ela promove uma troca, em que os participantes da comunidade relatam sobre suas vivências diárias relacionadas a possíveis situações de risco de PCR no dia-a-dia da casa, do trabalho ou escola; informam seus receios e a estranheza relacionados às manobras de RCP e assim, permitem que o acadêmico, por meio da reflexão e raciocínio, possa adequar todo o aprendizado teórico àquela experiência exposta e aprender com cada ser humano que ali se encontra, pois cada pessoa traz consigo um fragmento das diversas realidades que compõem sua comunidade, essa formada por diferentes níveis de ensino, cognição e economia, problemas sociais relacionados a drogas de abuso, discriminação racial e de gênero/ orientação sexual, entre outros. Assim, a extensão coloca o acadêmico na posição de peça principal na busca e formação do conhecimento, porém não um conhecimento alheio à realidade que o cerca, mas que dialoga e troca com a mesma no sentido de formar profissionais que saibam responder às demandas da sociedade e que compreendem o processo saúde-doença como um complexo sistema de variáveis sociais, ambientais e biológicas.

\section{CONCLUSÃO}

O projeto de extensão RCP para Todos é um espaço de fundamental importância devido a relevância do assunto, pois a correta identificação de uma PCR e o entendimento da manobra de RCP por parte da população leiga pode aumentar a sobrevida do paciente enquanto é aguardada a chegada de uma equipe profissional. Ademais, as experiências práticas da extensão permitem avanços importantes e positivos não somente em relação à promoção de saúde, autonomia e conhecimento da população, mas também permite o desenvolvimento da autonomia do acadêmico de medicina, a partir do momento em que ele se torna o responsável pelo seu processo de aprendizagem.

Durante o projeto, o acadêmico se vê envolvido desde a elaboração até a execução das ações, e assim, é possível, além da aquisição de conhecimentos, a troca de experiências e o desenvolvimento do olhar crítico frente a literatura, comparando-a com a prática. Dessa

Cidadania em Ação: Revista de Extensão e Cultura, Florianópolis (SC), v. 2, n.2, jul./dez. 2018. 
forma, a extensão contribui para a formação reflexiva e sintonizada com a realidade desses futuros médicos.

Conclui-se, portanto, que o projeto de extensão RCP para Todos constitui-se em um farto campo de práticas educativas aos moldes das metodologias ativas de ensinoaprendizagem e espera-se que através desse relato haja um aumento na valorização desses espaços como ferramenta de evolução da educação médica.

Cidadania em Ação: Revista de Extensão e Cultura, Florianópolis (SC), v. 2, n.2, jul./dez. 2018. 


\section{REFERÊNCIAS}

BERBEL, N. A. N. A problematização e a aprendizagem baseada em problemas: diferentes termos ou diferentes caminhos?. Interface-Comunicação, Saúde, Educação, v. 2, p. 139154, 1998. Disponível em:

http://www.scielo.br/scielo.php?pid=S141432831998000100008\&script=sci_abstract\&tlng=p t. Acesso em: 10 mai. 2018.

BORDENAVE, J. D.; PEREIRA, A. M. Estratégias de ensino-aprendizagem. 4. ed.

Petrópolis: Vozes, 1982. Disponível em:

https://www.uc.pt/fmuc/gabineteeducacaomedica/recursoseducare/livro17. Acesso em: 10 mai. 2018.

BRASIL. Ministério da Saúde (Org.). Sistema de Informações Sobre Mortalidade . Óbitos p/Ocorrência segundo Causa - CID-BR-10 Período: 2015-2016. 2017.Disponível em: http://www2.datasus.gov.br/DATASUS/index.php?area=0205\&id=6937. Acesso em: 08 mai. 2018.

DEUFEL, C. et al. A extensão como proposta de metodologia ativa de ensino-aprendizagem na Formação profissional: problematizações da experiência no projeto Semear Amigos.

Anais... Salão de Ensino e de Extensão, p. 100. 2014. Disponível em: http://online.unisc.br/acadnet/anais/index.php/salao_ensino_extensao/article/view/12495. Acesso em: 07 mai. 2018.

GONZALEZ, M. M. et al. I Diretriz de ressuscitação cardiopulmonar e cuidados cardiovasculares de emergência da Sociedade Brasileira de Cardiologia. Arquivos Brasileiros de Cardiologia, v. 101, n. 2, p. 1-221, 2013. Disponível em: http://publicacoes.cardiol.br/consenso/2013/Diretriz_Emergencia.pdf. Acesso em: 07 mai. 2018.

FREIRE, P. Pedagogia da autonomia: saberes necessários à prática docente. São Paulo: Paz e Terra, 1992.

LUCIANO, P. M. et al. Suporte básico de vida / Basic life support. Sociedade de Cardiologia Estado de São Paulo, São Paulo, p.230-238, jun. 2010.

MORAIS, D. A.; CARVALHO, D. V.; DOS REIS CORREA, A. Parada cardíaca extrahospitalar: fatores determinantes da sobrevida imediata após manobras de ressuscitação cardiopulmonar. Revista Latino-Americana de Enfermagem, v. 22, n. 4, 2014. Disponível em: http://www.revistas.usp.br/rlae/article/view/86649/89633. Acesso em: 09 mai de 2018.

PAZIN-FILHO, A. et al. Parada cardiorrespiratória (PCR). Medicina (Ribeirão Preto), v. 36, n. 2/4, p.163-178, 30 dez., 2003. Disponível em:

http://www.revistas.usp.br/rmrp/article/view/543. Acesso em: 06 mai. 2018.

PERGOLA, A. M.; ARAUJO, I. E. M. O leigo e o suporte básico de vida. Revista da Escola de Enfermagem da Usp, v. 43, n. 2, p.335-342, jun. 2009. Disponível em: http://www.revistas.usp.br/reeusp/article/view/40363. Acesso em: 10 mai 2018.

Cidadania em Ação: Revista de Extensão e Cultura, Florianópolis (SC), v. 2, n.2, jul./dez. 2018. 